\title{
Chemical Education Research in Slovenia after 1991: A Systematic Review
}

Iztok Devetak ${ }^{* 1}$ AND Vesna Ferk SAVeC ${ }^{2}$

$\approx$ During the last three decades, chemical education in Slovenia has developed mainly in two chemistry education research groups, one located at the University of Ljubljana and the other at the University of Maribor. The present study aims to identify research papers in the field of chemical education published between 1991 and 2019 through a database survey. From a total of 273 identified research papers in the field of chemical education, an analysis of the papers published in respected international and Slovenian journals and monographs revealed four main research fields: (1) Submicrorepresentations, Models and Animations, (2) Chemistry Teacher Education, (3) Experimental Work, and (4) Conceptions of Basic Chemical Concepts. For further analysis, only papers published in English in respected peer-reviewed international journals were used $(N=41)$. Based on citations in Web of Science or Scopus, it seems that papers published in the first field have the greatest impact on the international research community. Some research monographs published in Slovenian aim specifically at contributing to bridging the gap between chemical education research and classroom practice, but further actions are necessary to achieve this goal in the future.

Keywords: chemical education research, Slovenia, teaching and learning chemistry

$1 \quad{ }^{\star}$ Corresponding Author. Faculty of Education, University of Ljubljana, Slovenia; iztok.devetak@pef.uni-lj.si.

2 Faculty of Education, University of Ljubljana, Slovenia. 


\section{Raziskovanje v kemijskem izobraževanju v Sloveniji po letu 1991: sistematični pregled}

Iztok Devetak in Vesna Ferk Savec

$\propto$ V zadnjih treh desetletjih se je kemijsko izobraževanje v Sloveniji razvijalo predvsem v dveh raziskovalnih skupinah, ena na Univerzi v Ljubljani in druga na Univerzi v Mariboru. Namen te raziskave je na osnovi analize podatkov v bibliografskih bazah ugotoviti področja raziskovanja v kemijskem izobraževanju, objavljena med letoma 1991 in 2019. Od skupno 273 identificiranih raziskovalnih prispevkov s področja kemijskega izobraževanja, objavljenih $\mathrm{v}$ uglednih mednarodnih in slovenskih revijah in monografijah, je analiza razkrila štiri glavna raziskovalna področja: 1) submikroreprezentacije, modeli in animacije; 2) izobraževanje učiteljev kemije; 3) eksperimentalno delo; 4) razumevanje osnovnih kemijskih pojmov. Za nadaljnjo analizo so bili uporabljeni samo članki, objavljeni v angleškem jeziku v uglednih mednarodnih revijah $(N=41)$. Glede na citate, spremljane v Web of Science ali Scopus, se zdi, da prispevki, objavljeni na prvem področju, najbolj vplivajo na mednarodno raziskovalno skupnost. Prispevki, objavljeni v monografijah, objavljenih predvsem v slovenskem jeziku, pa prispevajo $\mathrm{k}$ premostitvi vrzeli med raziskovanjem v kemijskem izobraževanju in poukom kemije, vendar so za dosego tega cilja $\mathrm{v}$ prihodnosti potrebni nadaljnji ukrepi.

Ključne besede: raziskovanje v kemijskem izobraževanju, Slovenija, poučevanje in učenje kemije 


\section{Introduction}

In the 28 years of Slovenian independence, chemical education research has developed rapidly. The significance of national research lies in the development of new approaches that can be applied in specific professional activities, and this is also true for education. Cooperation between members of research groups can lead to progress in a specific field of research, including in chemical education research. This kind of cooperation is, however, quite weak in Slovenia. There are two major research groups in these fields, one at the University of Ljubljana and one at the University of Maribor. These two research groups have started to cooperate in some projects in the last few years. There are no research activities in the field of chemical education at the University of Primorska. The major focus of the present paper is to review research published in international peer-reviewed journals. However, there are also publications in Slovenian that chemistry teachers can easily read and apply the research results to practice (e.g., Devetak, 2007; Devetak \& Metljak, 2014; Ferk Savec \& Devetak, 2017; Glažar, Wissiak Grm, \& Devetak, 2019; Grubelnik, 2010). In the Slovenian context, there is also the journal Kemija $v$ šoli in družbi (Chemistry in School and Society), which is popular in school, but not as present as it should be in the chemical education research community. Similar problems can be identified with the journal Naravoslovna solnica (The Natural Science Saltcellar), which is not particularly relevant for chemistry teachers, but rather for teachers of earlier science at the preschool and primary school level.

\section{Chemical Education in the Slovenian School System}

Slovenian primary school education is organised in a single-structure nine-year basic school for students aged 6 to 15 years. It is mandatory, 99 percent public, and state financed. After entering basic compulsory nine-year education, students in primary education (aged 6-11; grades 1-5; Learning about the Environment, and Science and Technology courses) learn basic science concepts including chemical concepts, such as states of matter, mixtures and pure substances, basic separation methods, burning, air and water pollution, and solutions. Students aged from 12 to 13 years (grades 6 and 7) upgrade their knowledge of basic chemical concepts (chemical reactions, elements and compounds, particles of matter) in a course simply called Science. This level of compulsory basic education can be referred to as a lower secondary school. In the last two years of compulsory basic education, students are engaged in chemistry courses, because science is separated into three basic science courses 
(chemistry, biology and physics). The students are 14 to 15 years old and attend grades 8 and 9. At this point, they develop more specific chemical knowledge, as they are engaged in two years of chemistry classes. Topics range from the structure of atoms and molecules, to chemical reactions, properties of elements and their compounds, acids and bases, and organic chemistry topics (e.g., hydrocarbons, oxygen, and organic nitrogen compounds). After finishing basic compulsory education, students can proceed to the next level of education, which is two to four years of non-compulsory education. This upper secondary education can be: 1) four-year general upper secondary education (gimnazija), which prepares students to enter university and concludes with the Matura exam (external national final exam); and 2) vocational and technical upper secondary education, with programmes of various levels of difficulty (two- to four-year programmes). In gimnazija, students learn chemistry for three years, while those who choose chemistry as a Matura exam subject prepare for the external exam for an additional year. The chemistry topics are similar to those in lower secondary school, but upgraded (e.g., the orbitals of atoms, chemical equilibrium, redox reactions, organic chemical reactions, etc.).

Vocational and technical education programmes can have from zero to three years of chemical education, depending on the nature of the programme (e.g., economics has only one year of science, pharmacy has three years of chemistry similar to the chemistry in gimnazija). We can conclude that Slovenian students who finish general upper secondary school enter a university programme with five years of chemical education, and those who finish the chemistry Matura exam complete six years of advanced chemical education (Torkar \& Devetak, 2018).

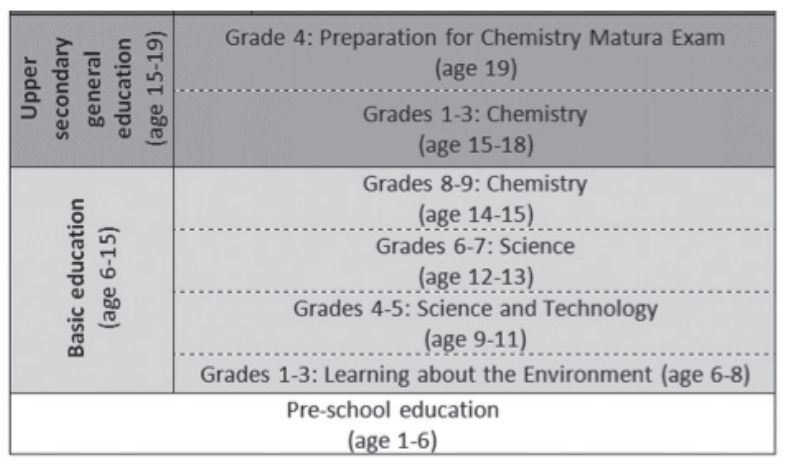

Figure 1. The structure of chemistry education in Slovenia. Adapted from Devetak \& Ferk Savec, 2018. 


\section{The Beginnings of Slovenian Chemical Education Research}

One of the most important landmarks in Slovenian chemical education research can be identified in the first issue of the International Journal of Science Education (entitled the European Journal of Science Education at that time). Aleksanda Kornhauser Frazer wrote a review paper identifying key trends in chemical education research in the late 1970s, dealing with visionary issues of chemical education. Entitled Trends in Research in Chemical Education, the paper projected future aspects of research in chemical education following an extensive review of the then recent research in chemical education. The review analysed some 250 different papers published mainly in the period 1975-77, under the following keywords: general research in chemical education, content-oriented research, research into methods of chemical education, teaching aids and the use of educational technology, and research in assessment and evaluation (Kornhauser, 1979). Since then, research has significantly influenced chemical education in Slovenia at all levels of education, both on the systemic level in curriculum development as well as in school practice.

Judging by the trends presented in the review paper 40 years ago, similar topics have remained interesting in the chemical education research community both internationally and in the Slovenian context. However, a more detailed analysis of the chemistry education research field in Slovenia since its independence in 1991 is needed.

\section{Research Problem}

The present study was carried out to survey papers published by recognised scientific journals from 1991 to 2019, with the aim of examining evidence from chemistry education research conducted in the Slovenian context. The main focus is on reviewing chemistry education research in Slovenia after 1991 and evaluating the research methodologies and research results that could influence chemistry learning.

Based on this research focus, the following research question can be formed:

- What are the characteristics of Slovenian research papers published between 1991 and 2019, and what are the main findings that could help to determine which aspects teachers should consider when teaching abstract chemical concepts at all levels of chemistry education? 


\section{Method}

A systematic review of research papers in the field of chemistry education research in Slovenian in the last 28 years was undertaken. In accordance with the definition of "systematic review", we combined evidence from multiple studies by identifying relevant research, appraising study quality and summarising findings. The systematic approach of a literature review uses systematic methods to collect secondary data, critically appraise research studies and synthesise findings qualitatively or quantitatively. Systematic reviews formulate research questions to identify and synthesise studies that directly relate to the systematic review's research problem. With such studies, a complete, exhaustive summary of current evidence relevant to a research question is provided (Smith et al., 2011).

\section{Search strategy}

In the first step of the study, we determined the following inclusion criteria: (1) the study was written by Slovenian authors, (2) the study was related to chemistry learning, (3) primary, secondary and university students participated in the study, and (4) the study was conducted between 1991 and 2019, was peer reviewed and was reported in English. Relevant studies were selected based on these criteria.

The Slovenian Current Research Information System (SICRIS) database was used to identify the relevant Slovenian authors. This database is supported by the Information Service for Slovenian Science, Culture and Education (IZUM) and the Slovenian Research Agency (ARRS). The main search classification was used following the scientific field as social science, the area of education and the subarea of special didactics. A total of 255 researchers were identified. After screening the researchers' database, 22 chemical education researchers were identified.

A specific research algorithm was applied to the SICRIS database to identify all peer-reviewed research papers written by these 22 chemical education researchers and published in English by journals or as chapters of monographs. Papers in respected peerreviewed journals and international monographs were included in the systematic review.

Through this research, a total of 148 journal papers and 125 monograph chapters were identified for further analyses. The final selection of the journal papers and monograph chapters was conducted using the PRISMA (Preferred Reporting Items for Systematic Reviews and Meta-Analyses, Moher et al., 2009) flow diagram (Figure 2).

Content analysis was performed on the 41 selected studies that are exclusively from the chemical education field. Descriptions of four topics were examined: (1) participants, (2) supported methods, (3) chemistry content, and (4) basic results applicable in the school context. The papers that were not analysed were from other fields of science education. 


\section{Selection of studies and data extraction}

Two authors (ID and VFS) independently checked the titles and abstracts identified in the search. They examined the full texts of the studies for possible relevance for assessment, decided which papers met the inclusion criteria, and specified the codes and categories formed by extracting relevant data from the included studies. The authors then met to compare and confirm the results. Any disagreements were resolved by discussion between the authors. If there were not enough data about a certain content-analysis criterion, the corresponding author of the specific paper was contacted for additional information on methodology or results. If no response was obtained within three weeks after two separate written requests, the analysis was done using the available data.

\section{Results and discussion}

The search identified 273 papers from researchers in the field of chemical education in Slovenia in the last 28 years, published in journals and monographs. After screening the titles and abstracts, 113 papers were selected for full-text screening (Figure 2). The main reason for rejecting 160 papers was that the articles did not discuss research problems from the field of chemical education in Slovenia in the last 28 years. After contacting the authors of unpublished research regarding the aim of our study, no additional papers were received. Some 15 research fields were identified and 113 papers and monograph chapters were arranged in these fields (Table 1).
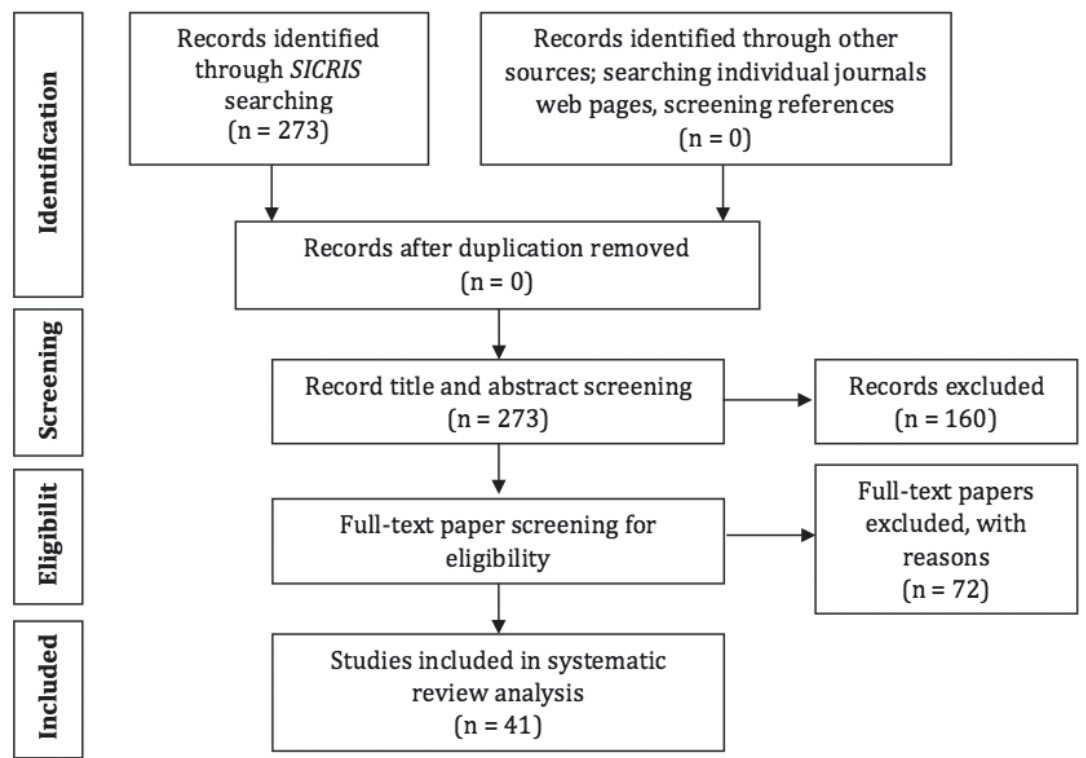

Figure 2. PRISMA flow diagram for our study. Adapted from Moher et al., 2009. 
As can be seen in Figure 2, 72 of the journal papers and monograph chapters were excluded because the papers were in Slovenian, Bosnian or French, or because they explored problems other than chemical education (e.g., chemistry, science informatics, science education in general, technology education, curriculum development, higher education quality, teachers' medical education and so on). A total of 41 published papers (Figure 2 and Table 1 ) met the inclusion criteria of (1) chemical education research paper, (2) publication in a peer-reviewed international journal, and (3) language of publication is English.

Table 1

The research focuses identified in Slovenian research reports and the number of papers and chapters published in these research areas

\begin{tabular}{|c|c|c|c|}
\hline \multirow[b]{2}{*}{ Research Focus } & \multirow{2}{*}{$\begin{array}{l}\text { Language of } \\
\text { Publication }\end{array}$} & \multicolumn{2}{|c|}{ Type of Research Publication } \\
\hline & & $\begin{array}{c}\text { Journal Paper } \\
f / f \%\end{array}$ & $\begin{array}{l}\text { Monograph Chapter } \\
f / f \%\end{array}$ \\
\hline \multirow{2}{*}{$\begin{array}{l}\text { Submicro Representations, Models and } \\
\text { Animations* }\end{array}$} & Slo. & - & $3 / 6$ \\
\hline & Eng. & $14 / 21$ & $2 / 4$ \\
\hline \multirow{2}{*}{ Chemistry Teacher Education* } & Slo. & $1 / 2$ & $3 / 6$ \\
\hline & Eng. & $10 / 15$ & $6 / 13$ \\
\hline \multirow{2}{*}{ Experimental Work* } & Slo. & - & $7 / 15$ \\
\hline & Eng. & $9 / 14$ & $2 / 4$ \\
\hline \multirow{2}{*}{ Conceptions of Basic Chemical Concepts* } & Slo. & $2 / 3$ & $6 / 13$ \\
\hline & Eng. & $8 / 12$ & $1 / 2$ \\
\hline \multirow{2}{*}{ Environmental Chemistry } & Slo. & $1 / 2$ & $3 / 6$ \\
\hline & Eng. & $5 / 8$ & - \\
\hline \multirow{2}{*}{ Interdisciplinary Education } & Slo. & - & $1 / 2$ \\
\hline & Eng. & $2 / 3$ & - \\
\hline \multirow{2}{*}{ Context-Based Learning } & Slo. & - & $3 / 6$ \\
\hline & Eng. & $1 / 2$ & $1 / 2$ \\
\hline \multirow{2}{*}{ Motivation \& Performance in Chemistry } & Slo. & $1 / 2$ & $1 / 2$ \\
\hline & Eng. & $2 / 3$ & $2 / 4$ \\
\hline \multirow{2}{*}{ Assessment of Knowledge in Chemistry } & Slo. & $1 / 2$ & $1 / 2$ \\
\hline & Eng. & $1 / 2$ & $1 / 2$ \\
\hline \multirow{2}{*}{$\begin{array}{l}\text { History of Chemistry and Chemical Educa- } \\
\text { tion }\end{array}$} & Slo. & $3 / 5$ & - \\
\hline & Eng. & - & - \\
\hline \multirow{2}{*}{ Inquiry-Based Chemical Education } & Slo. & - & - \\
\hline & Eng. & $1 / 2$ & - \\
\hline \multirow{2}{*}{ Concept Mapping } & Slo. & - & - \\
\hline & Eng. & $2 / 3$ & $1 / 2$ \\
\hline \multirow{2}{*}{$\begin{array}{l}\text { The Relevance of Chemical Education, } \\
\text { School-University-Industry Collaboration }\end{array}$} & Slo. & - & $1 / 2$ \\
\hline & Eng. & - & $1 / 2$ \\
\hline \multirow{2}{*}{ Stoichiometry } & Slo. & - & - \\
\hline & Eng. & $1 / 2$ & - \\
\hline
\end{tabular}




\begin{tabular}{llcc}
\hline \multirow{2}{*}{ Research Focus } & Language of & \multicolumn{2}{c}{ Type of Research Publication } \\
\cline { 3 - 4 } & Publication & $\begin{array}{c}\text { Journal Paper } \\
f / f \%\end{array}$ & $\begin{array}{c}\text { Monograph Chapter } \\
f / f \%\end{array}$ \\
\hline \multirow{2}{*}{ Education of the Gifted } & Slo. & - & - \\
& Eng. & $1 / 2$ & $1 / 2$ \\
\hline \multirow{2}{*}{ Total } & Slo. & $9 / 14$ & $29 / 62$ \\
& Eng. & $57 / 86$ & $18 / 38$ \\
\hline
\end{tabular}

Note. Research focuses that were analysed in more detail due to the fact that they were identified as the main research fields of Slovenian chemistry education researchers (papers in peer-review journals in English $n=41$ ).

An analysis of papers published in respected international and Slovenian journals and monographs identified four main research focuses: (1) Submicrorepresentations, Models and Animations, (2) Chemistry Teacher Education, (3) Experimental Work, and (4) Conceptions of Basic Chemical Concepts. A total of 75 papers and monograph chapters were published in English and Slovenian focusing on these four topics. For further analysis, only papers published in English in respected peer-reviewed international journals were used. There were 41 papers in this category (Figure 2 and Table 1 ).

\section{Characteristics of the Analysed Studies}

The analysed studies were divided into four sub-sections of the main research fields:

(1) Submicrorepresentations, Models and Animations, (2) Chemistry Teacher Education, (3) Experimental Work, and (4) Conceptions of Basic Chemical Concepts.

\section{Submicrorepresentations, Models and Animations}

One of the largest research areas concerns Submicrorepresentations, Models and Animations used in chemical education. The characteristics of papers published in the last 28 years by Slovenian chemical education researchers in this area are presented in Table 2. It can be concluded that the majority of these papers have had an impact on the international chemical education research community, because all of those published before 2018 in respected peer-reviewed international journals have at least one citation in Web of Science or Scopus. 
Table 2

Characteristics of the analysed papers that met the inclusion criteria in the research field of Submicrorepresentations, Models and Animations (listed according to publication year)

\begin{tabular}{lll}
\hline Authors & Title & Characteristics* $^{*}$ \\
\hline Ferk Savec, V., & Students' understanding of molecular & J: International Journal of Science \\
Vrtačnik, M., Blejec, & structure representations & Education \\
A., Gril, A. & & ISSN: 0950-0693; PY: 2003; PP: \\
& & 18; NoR: 55 \\
& & NoCit: Wos 77 Scopus 92 \\
\hline
\end{tabular}

Devetak, I., Urbančič, Submicroscopic representations as a M., Wissiak Grm, K. tool for evaluating students' chemical S., KrneL, D., Glažar, conceptions S. A.

Ferk Savec, V., Vrtačnik, M., Gilbert, J. K., Peklaj, C. In-service and pre-service teachers' opinion on the use of models in teaching chemistry

\begin{tabular}{ll}
\hline Devetak, I., Vogrinc, & Assessing 16-year-old students' \\
J., Glažar, S. A. & understanding of aqueous solution at \\
& submicroscopic level
\end{tabular}

Devetak, I., Hajzeri, The influence of different models on M., Glažar, S. A., Vogrinc, J. 15-years-old students' understanding of the solid state of matter

Devetak, I., Glažar, S. A.

The influence of 16-year-old students' gender, mental abilities, and motivation on their reading and drawing submicrorepresentations achievements

Devetak, I., Vogrinc, States of matter explanations in J., Glažar, S. A Slovenian textbooks for students aged 6 to 14

\begin{tabular}{|c|c|c|}
\hline & & NoR: 40 \\
\hline & & NoCit: $\quad$ Scopus 7 \\
\hline $\begin{array}{l}\text { Sikošek, D., Žuželj, } \\
\text { M. }\end{array}$ & $\begin{array}{l}\text { Using chemical models for developing } \\
\text { natural science competences in teach- } \\
\text { ing chemistry: from pupils as model } \\
\text { assemblers to pupils as creators of } \\
\text { self-made models }\end{array}$ & $\begin{array}{l}\text { J: Problems of Education in the } \\
27^{s t} \text { Century } \\
\text { ISSN: } 1822-7864 \text {; PY: 2013; PP: 9; } \\
\text { NoR: } 20\end{array}$ \\
\hline Nuić, I.,Glažar, S. A. & $\begin{array}{l}\text { Application of web-based learning } \\
\text { material for teaching states of matter } \\
\text { in } 8^{\text {th }} \text { grade primary school chemistry } \\
\text { - a pilot study results }\end{array}$ & $\begin{array}{l}\text { J: Glasnik Hemičara i Tehnologa } \\
\text { Bosne i Hercegovine } \\
\text { ISSN: 0022-9830; PY: 2015; PP: } \\
\text { 7; NoR: } 25\end{array}$ \\
\hline $\begin{array}{l}\text { Ferk Savec, V., } \\
\text { Hrast, Š., Devetak, I., } \\
\text { Torkar, G. }\end{array}$ & $\begin{array}{l}\text { Beyond the use of an explanatory } \\
\text { key accompanying submicroscopic } \\
\text { representations }\end{array}$ & $\begin{array}{l}\text { J: Acta Chimica Slovenica } \\
\text { ISSN: 1318-0207; PY: 2016; PP: 9; } \\
\text { NoR: } 43 \\
\text { NoCit: Wos } 4 \quad \text { Scopus } 6\end{array}$ \\
\hline
\end{tabular}

J: Acta Chimica Slovenica

ISSN: 1318-0207; PY: 2004; PP: 15; NoR: 22

NoCit: Wos 15 Scopus 13

J: Acta Chimica Slovenica

ISSN: 1318-0207; PY: 2006; PP: 9;

NoR: 18

NoCit: Wos 5 Scopus 5

$\mathrm{J}$ : Research in Science Education

ISSN: 0157-244X; PY: 2009; PP:

22; NoR: 46

NoCit: Wos 32 Scopus 40

J: Acta Chimica Slovenica

ISSN: 1318-0207; PY: 2010; PP: 7;

NoR: 37

NoCit: Wos 2 Scopus 4

$\mathrm{J}$ : International Journal of Science

Education

ISSN: 0950-0693; PY: 2010; PP:

32; NoR: 52

NoCit: Wos 17 Scopus 15

$\mathrm{J}$ : International Journal of Environ-

mental and Science Education
ISSN: 1306-3065; PY: 2010; PP: 18;

NoR: 40

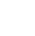




\begin{tabular}{|c|c|c|}
\hline Authors & Title & Characteristics* \\
\hline \multirow[t]{2}{*}{$\begin{array}{l}\text { Hrast, Š., Ferk } \\
\text { Savec, V. }\end{array}$} & \multirow[t]{2}{*}{$\begin{array}{l}\text { The integration of submicroscopic } \\
\text { representations used in chemistry } \\
\text { textbook sets into curriculum topics }\end{array}$} & $\begin{array}{l}\text { J: Acta Chimica Slovenica } \\
\text { ISSN: 1318-0207; PY: 2017; PP: 8; } \\
\text { NoR: } 34\end{array}$ \\
\hline & & NoCit: Wos $0 \quad$ Scopus 1 \\
\hline \multirow[t]{2}{*}{$\begin{array}{l}\text { Hrast, Š., Ferk } \\
\text { Savec, V. }\end{array}$} & \multirow[t]{2}{*}{$\begin{array}{l}\text { Informational value of submicroscopic } \\
\text { representations in Slovenian chemis- } \\
\text { try textbook sets }\end{array}$} & \multirow[t]{2}{*}{$\begin{array}{l}\text { J: Journal of Baltic Science Educa- } \\
\text { tion } \\
\text { ISSN: } 2538-7138 ; \text { PY: 2017; PP: 11; } \\
\text { NoR: } 30 \\
\text { NoCit: Wos } 0 \quad \text { Scopus } 1\end{array}$} \\
\hline & & \\
\hline \multirow[t]{2}{*}{$\begin{array}{l}\text { Torkar, G., Veldin, } \\
\text { M., Glažar, S. A., } \\
\text { Podlesek, A. }\end{array}$} & \multirow[t]{2}{*}{$\begin{array}{l}\text { Why do plants wilt? Investigating stu- } \\
\text { dents' understanding of water balance } \\
\text { in plants with external representations } \\
\text { at the macroscopic and submicrosco- } \\
\text { pic levels }\end{array}$} & \multirow[t]{2}{*}{$\begin{array}{l}\text { J: Eurasia Journal of Mathematics, } \\
\text { Science and Technology Education } \\
\text { ISSN: 1305-8223; PY: 2018; PP: 11; } \\
\text { NoR: } 44 \\
\text { NoCit: Wos } 0 \quad \text { Scopus } 0\end{array}$} \\
\hline & & \\
\hline \multirow[t]{2}{*}{$\begin{array}{l}\text { Pavlin, J., Glažar, } \\
\text { S.A, Slapničar, M., } \\
\text { Devetak, I. }\end{array}$} & \multirow{2}{*}{$\begin{array}{l}\text { The impact of students' educa- } \\
\text { tional background, interest in learning, } \\
\text { formal reasoning and visualization } \\
\text { abilities on gas context-based exer- } \\
\text { cises achievements with submicro- } \\
\text { animations }\end{array}$} & $\begin{array}{l}\text { J: Chemistry Education Research } \\
\text { and Practice } \\
\text { ISSN: 1756-1108; PY: 2019; PP: 16; } \\
\text { NoR: } 79\end{array}$ \\
\hline & & NoCit: Wos $0 \quad$ Scopus 0 \\
\hline
\end{tabular}

Note. $\mathrm{J}=$ Journal; $\mathrm{PY}=$ Publication Year; $\mathrm{PP}=$ No. of pages; $\mathrm{R}=$ No. of references; NoCit $=$ Number of citations in Web of Science (WoS) and Scopus (citations until 16.08.19).

A more detailed analysis of the research problems and main conclusions of these papers indicates that the most important subfield was research of students' understanding of molecular representations, such as various models and modelling activities. Ferk Savec, Vrtačnik, Blejec and Gril (2003) investigated the meanings attached by students to the different kinds of molecular structure representations used in chemistry teaching. The research indicates that students' appreciation of three-dimensional molecular structures differs according to the kind of representation used. The best results were achieved with the use of concrete and pseudo-concrete types of representations (e.g., three-dimensional models, their photographs, computer-generated models), while the use of more abstract types (e.g., schematic representations, stereochemical formula) was less effective. Similar research was conducted by Sikošek and Žuželj (2013) investigating students' ability to assemble commercial models and oversee the production of self-made models. The research showed that this activity leads to a better understanding of chemical concepts and subsequently sustained knowledge. It is also important to emphasise that students who model their own models develop more complete skills in the areas of problem-solving, practical competences, mathematical competences and critical thinking skills. Multi-modelling activities (the use of physical models in teachers' demonstrations, student modelling, and virtual models of solid states in the educational process) aimed at acquiring a better understanding of the crystal structures of substances were also researched in a study involving first-year general upper 
secondary school students (Devetak, Hajzeri, Glažar, \& Vogrinc, 2010). The results indicate that the students who modelled physical models scored better on a post-test than both those who used virtual models and those who were taught the solid state of matter by the teachers' demonstration of physical models. It can be concluded that students who are engaged in active learning strategies that include modelling or computer interaction using virtual models develop more adequate mental models of solid-state substance structures. There were also studies of teachers' opinions about using models in chemistry teaching. Many teachers claimed that $3 \mathrm{D}$ models are still not available in sufficient numbers at their schools; they also pointed out a lack of available computer facilities during chemistry lessons. The research revealed that, besides the inadequate material circumstances, less than one-third of the participants were able to use simple (freeware) computer programs for drawing molecular structures and their presentation in virtual space; however, both groups of teachers expressed a willingness to improve their knowledge in the subject area. The investigation indicates several actions that could be undertaken to improve the current situation (Ferk Savec, Vrtačnik Gilbert, \& Peklaj, 2006).

A large body of research concerns the importance of integrating the triple nature of chemical concepts, especially submicrorepresentations of substances, into teaching, and the correlations between different students' abilities and understanding of chemical concepts at the submicro level. In this regard, Devetak, Urbančič, Wissiak Grm, Krnel and Glažar (2004) concluded that students who had chosen chemistry as part of their Matura exam (final external examination at the end of upper secondary school before entering the university) achieved better results in problems involving basic chemical concepts about solutions, acids and bases, as well as equilibria based on submicrorepresentations, than those who had not. The authors found that students who took the Matura exam prepared for the exam by practising linking the three levels of chemical concepts (macro, submicro and symbolic). However, this way of learning and teaching chemistry was rarely practised in Slovenian secondary schools at that time.

In a study by Devetak, Vogrinc and Glažar (2009), the authors investigated the level of upper secondary school students' understanding of solution concentration and the process of dissolving ionic and molecular crystals at the particulate level. Possible misconceptions about this process were identified in the study. Students showed rather low achievement scores in the problem regarding drawing the SMR of an ionic substance aqueous solution (7.6\% correct answers), and an even lower success rate in a problem regarding drawing the SMR of diluted and saturated aqueous solutions of a molecular crystal (no completely correct answers). 
The use of animated submicrorepresentations in biochemical systems was researched by Torkar, Veldin, Glažar and Podlesek (2018), who applied the eye tracking methodology to measure students' attention to different parts of a presentation of osmosis. It was established that the students who were more successful in providing correct answers to the tasks at the multi-level of concept presentations spent less time processing information provided by the macro photo of the plant and the submicro animation of the osmosis in the plants' cell. Using the eye tracking methodology to assess participants' visual attention to specific elements at the explanatory key of submicrorepresentations was also examined in research by Ferk Savec, Hrast, Devetak and Torkar (2016). Eye-fixation patterns and students' verbal explanations indicated that the presence of colour in the key does not influence students' task solving. The results indicate that the type of explanatory key may play an important role in revealing students' representational competence with regard to submicroscopic representations.

In addition, two papers were published explaining how students' different abilities can influence their achievements in solving a submicrorepresentations problem. The results show moderate but statistically significant correlations between students' intrinsic motivation, formal reasoning abilities and chemical knowledge at the submicroscopic level, based on reading and drawing submicrorepresentations. Visualisation abilities are not statistically significantly correlated with students' success on items that comprise reading or drawing submicrorepresentations (Devetak \& Glažar, 2010). A similar study was conducted by Pavlin, Glažar, Slapničar and Devetak (2019). The context-based gas exercise is indicated as being difficult for students. Difficulties are detected in students' explanations of different levels of chemical concepts and representation. Students' achievements in solving context-based gas exercises do not depend on interest in learning chemistry and visualisation abilities. However, statistically significant differences exist in total fixation duration on the correct submicrorepresentation animation between students with different formal reasoning abilities.

Four papers examined the importance of integrating the submicro level of chemical concepts in chemistry textbooks or online learning materials. The basic aim of a study by Devetak, Vogrinc and Glažar (2010) was to investigate the content of textual and pictorial material in Slovenian science textbooks and notebooks on the topic of states of matter. The paper presents the results of an analysis of educational material from two randomly selected publishers for students aged 6 to 14 in Slovenian primary and lower secondary schools. The results reveal quite a few similarities between the analysed textbooks (number of 
pages, type of items), but some differences could be detected when comparing the type of images in the educational material. Content analysis of the selected textbooks also shows that they retain the content directed by the national curriculum, but the ways (examples, content of the images, etc.) in which authors present the topics differ. A paper by Hrast and Ferk Savec (2017a), entitled The Informational Value of Submicroscopic Representations in Slovenian Chemistry Textbook Sets, describes four holistic submicro representation descriptors (direct, indirect, combined descriptor and submicro representations without descriptors) that support learners' recognition of the informational value of submicro representations at different levels by providing different accompanying submicro representation add-ons. The same authors also published the paper Hrast and Ferk Savec (2017b), in which they focus on how submicroscopic representations are integrated into Slovenian chemistry textbooks. The analysis of textbook sets revealed that the number of submicroscopic representations varies significantly with regard to different curriculum topics, but that the overall proportion of the descriptors that enable the learner direct recognition of submicro representations is low in all curriculum topics. The final paper in this group deals with the results of a study that investigated the progression in primary school students' conceptions of the structure and states of matter while learning with a new web-based instructional approach containing macro and submicro representations. The results showed a better understanding of the structure and states of matter, but also revealed some persistent misconceptions that could be addressed in further research (Nuić \& Glažar, 2015).

\section{Chemistry Teacher Education}

An analysis of publications in the field of Chemistry Teacher Education revealed that researchers focused on three main aspects of preservice and inservice chemistry teacher training: active learning, the role of teaching practice, and international collaboration. The citations of these papers are low. 
Table 3

Characteristics of the analysed papers that met the inclusion criteria in the research field of Chemistry Teacher Education (listed according to publication year)

\begin{tabular}{|c|c|c|}
\hline Authors & Title & Characteristics* \\
\hline Sikošek, D. & $\begin{array}{l}\text { Student self-evaluation of co-lecture } \\
\text { activities }\end{array}$ & $\begin{array}{l}\text { J: Problems of Education in the } 27^{\text {st }} \\
\text { Century } \\
\text { ISSN: } 1822-7864 \text {; PY: 2009; PP: 6; } \\
\text { NoR: } 6\end{array}$ \\
\hline Sikošek, D. & $\begin{array}{l}\text { Student self-evaluation of seminar } \\
\text { activities }\end{array}$ & $\begin{array}{l}\text { J: Problems of Education in the } 27^{\text {st }} \\
\text { Century } \\
\text { ISSN: 1822-7864; PY: 2009; PP: 6; NoR: } 8\end{array}$ \\
\hline $\begin{array}{l}\text { Ferk Savec, } \\
\text { V., Devetak, I. }\end{array}$ & $\begin{array}{l}\text { Evaluating the effectiveness of stu- } \\
\text { dents' active learning in chemistry. }\end{array}$ & $\begin{array}{l}\text { J: Procedia - Social and Behavioral } \\
\text { Sciences } \\
\text { ISSN: 1877-0428; PY: 2013; PP: 8; NoR: } 9 \\
\text { NoCit: } \quad \text { Scopus } 0\end{array}$ \\
\hline $\begin{array}{l}\text { Wissiak Grm, } \\
\text { K. S., Ferk } \\
\text { Savec, V. }\end{array}$ & $\begin{array}{l}\text { Bridging the gap between educational } \\
\text { research and school practice through } \\
\text { cooperation of university and primary } \\
\text { school teachers. }\end{array}$ & $\begin{array}{l}\text { J: Procedia - Social and Behavioral } \\
\text { Sciences } \\
\text { ISSN: 1877-0428; PY: 2013; PP: 8; NoR: } 11 \\
\text { NoCit: } \quad \text { Scopus } 0\end{array}$ \\
\hline $\begin{array}{l}\text { Sikošek, D., } \\
\text { Žarić, K. }\end{array}$ & $\begin{array}{l}\text { Implementation of process-targeted } \\
\text { activities of prospective chemistry } \\
\text { teachers during continuous teaching } \\
\text { practice: a rational comparative analysis } \\
\text { of teaching methods according to the } \\
\text { expressed competencies. }\end{array}$ & $\begin{array}{l}\text { J: Problems of Education in the } 27^{\text {st }} \\
\text { Century } \\
\text { ISSN: 1822-7864; PY: 2013; PP: 14; NoR: } \\
16\end{array}$ \\
\hline $\begin{array}{l}\text { Wissiak Grm, } \\
\text { K. S., Ferk } \\
\text { Savec, V. }\end{array}$ & $\begin{array}{l}\text { The self-evaluation of Slovenian pro- } \\
\text { spective chemistry teachers' progress } \\
\text { during their practical pedagogical train- } \\
\text { ing in primary schools. }\end{array}$ & $\begin{array}{l}\text { J: Acta Chimica Slovenica } \\
\text { ISSN: 1318-0207; PY: 2014; PP: 8; NoR: } \\
20 \\
\text { NoCit: Wos } 3 \quad \text { Scopus } 3\end{array}$ \\
\hline $\begin{array}{l}\text { Ferk Savec, } \\
\text { V., Urankar, } \\
\text { B., Aksela, M., } \\
\text { Devetak, I. }\end{array}$ & $\begin{array}{l}\text { Prospective chemistry teachers' per- } \\
\text { ceptions of their profession: the state of } \\
\text { the art in Slovenia and Finland }\end{array}$ & $\begin{array}{l}\text { J: Journal of the Serbian Chemical } \\
\text { Society } \\
\text { ISSN: } 1820-7421 ; \text { PY: 2017; PP: 17; NoR: } \\
57 \\
\text { NoCit: Wos } 0 \quad \text { Scopus } 0\end{array}$ \\
\hline $\begin{array}{l}\text { Ferk Savec, } \\
\text { V., Wissiak } \\
\text { Grm, K. S. }\end{array}$ & $\begin{array}{l}\text { Development of chemistry pre-service } \\
\text { teachers during practical pedagogical } \\
\text { training: self-evaluation vs. evaluation } \\
\text { by school mentors. }\end{array}$ & $\begin{array}{l}\text { J: Acta Chimica Slovenica } \\
\text { ISSN: 1318-0207; PY: 2017; PP: 9; NoR: } 27 \\
\text { NoCit: Wos } 1 \quad \text { Scopus } 1\end{array}$ \\
\hline $\begin{array}{l}\text { Ferk Savec, } \\
\text { V., Hrast, Š., } \\
\text { Šuligoj, V., } \\
\text { Avsec, S. }\end{array}$ & $\begin{array}{l}\text { The innovative use of ICT in STEM } \\
\text { teacher training programmes at the } \\
\text { University of Ljubljana. }\end{array}$ & $\begin{array}{l}\text { J: World Transactions on Engineering } \\
\text { and Technology Education } \\
\text { ISSN: 1446-2257; PY: 2018; PP: 6; NoR: } \\
16 \\
\text { NoCit: Wos } 0 \quad \text { Scopus } 0\end{array}$ \\
\hline $\begin{array}{l}\text { Kousa, P., } \\
\text { Aksela, M., } \\
\text { Ferk Savec, V. }\end{array}$ & $\begin{array}{l}\text { Pre-service teachers' beliefs about the } \\
\text { benefits and challenges of STSE based } \\
\text { school-industry collaboration and } \\
\text { practices in science education. }\end{array}$ & $\begin{array}{l}\text { J: Journal of Baltic Science Education } \\
\text { ISSN: 2538-7138; PY: 2018; PP: 11; NoR: } 41 \\
\text { NoCit: Wos } 0 \quad \text { Scopus } 0\end{array}$ \\
\hline
\end{tabular}

Note. $\mathrm{J}=$ Journal; $\mathrm{PY}=$ Publication Year; $\mathrm{PP}=$ No. of pages; $\mathrm{R}=$ No. of references; NoCit $=$ Number of citations in Web of Science (WoS) and Scopus (citations until 16.08.19). 
As many as five articles in this field focused on active learning in preservice and in-service chemistry teacher training, strategies for facilitating the active role of students, and the role of ICT (Information and Communication Technology) in the learning process. Sikošek (2009a) analysed active learning approaches in the chemistry teacher education programme at the Faculty of Education of the University of Maribor (i.e., the subjects Didactics of Chemistry, Experiments, and Natural Activities-Mentorship). The research showed that co-lecture activities were valued regarding optional AADIDG (Activity, Autonomy, Differentiation and Individualisation, Democracy, and Gradual Study) didactic principles. Later, Sikošek (2009b) focused on the curricular innovations of methodological subjects for chemistry teachers at undergraduate education at the University of Maribor. The redesign of the seminar, understood as an essential curricular form, was based on ongoing consideration of topical didactic principles. Thereby, their research findings aimed to serve the optimisation of the performance of activities during the seminar. Other researchers (Ferk Savec, Hrast, Šuligoj, \& Avsec, 2018) focused on the development of preservice teachers' competencies related to the use of ICT, which is necessary for the successful implementation of ICTsupported innovative approaches and effective teaching and learning in their future school practice. The renewed study subjects were also studied based on the theoretical framework of the SAMR (Substitution, Augmentation, Modification and Redefinition) model, which defines four different degrees of ICT integration in the learning process. Regarding in-service teacher training, Ferk Savec and Devetak (2013) evaluated the active learning approach PROFILES. The results underline various advantages of the treatment classes with the use of approach PROFILES in comparison to regular chemistry classes, when guided by trained in-service chemistry teachers, but also indicate that $8^{\text {th }}$ graders need some time to adapt to the innovative learning strategy. With regard to in-service teacher training, Wissiak Grm and Ferk Savec (2013) focused on the gap between chemistry education research and teaching practice, reporting about a collaboration between researchers at the University of Ljubljana and in-service teachers in the PROFILES project. The findings point out the importance of very concise and unequivocal instructions for in-service teachers to ensure that all parts of the project are performed in line with the research plan.

The next three papers focused on the role of teaching practice and the experiences that students gain during practice at schools. Sikošek and Žarić (2013) pointed out that teachers of chemistry need to gain or develop learner competencies for appropriate teaching/learning in the subject of chemistry by using innovative teaching methods. The main result of the study was a list of potential competencies by prospective chemistry teachers using innovative 
teaching methods. Wissiak Grm and Ferk Savec (2014) conducted a study about students performing teaching practice. An analysis of the results revealed that students believe that teaching practice makes a crucial contribution to their education in light of their future profession. A similar study was conducted later by Ferk Savec and Wissiak Grm (2017), who studied the self-evaluation of the progress of $4^{\text {th }}$ year preservice chemistry teachers during their second year teaching practice in primary schools in comparison to the perception of their progress by their school mentors. The results revealed that student teachers were stricter in their self-evaluation than their school mentors after their first chemistry lecture at school; however, after their last lecture, the evaluations were similar for most of the studied characteristics.

The last two papers in the chemistry teacher education field dealt with international collaboration and exchange of experiences in preservice chemistry teacher training. The researchers (Ferk Savec, Urankar, Aksela, \& Devetak, 2017) especially with regard to their understanding of the role of the triple nature of chemical concepts (macro, submicro and symbolic studied Slovenian and Finnish preservice chemistry teachers' perceptions of their future profession. The results indicate that the majority of preservice teachers from both countries believe that personal characteristics, enthusiasm and understanding the triple nature of chemical concepts are the most important attributes of a successful chemistry teacher. A further study (Kousa, Aksela, \& Ferk Savec, 2018)teachers' negative beliefs, lack of knowledge, resources, support and opportunities to collaborate with companies can impede the efficient implementation. In this case-study, 42 Finnish and Slovenian pre-service teachers' STSE beliefs were first examined before and after the school-industry collaboration course by survey. After the course, beliefs of 8 Finnish pre-service teachers were analyzed in more detail by open-ended questionnaires and reflective writing. The pre-service teachers were more confident to teach STSE issues after the course in both countries. However, they needed more support and knowledge from the community members they collaborated with (i.e. representatives of industries, university teacher, student colleagues and school teachers of Slovenian and Finnish preservice chemistry teachers focused on their science, technology, society and environment (STSE) beliefs. The preservice teachers needed more support and knowledge from the community members they collaborated with (i.e., representatives of industries, university teachers, student colleagues and school teachers). The results of this research highlight the importance of preservice teacher education and practices with STSE issues, and pointed out that both positive and negative beliefs should be examined frequently even during preservice education in order to develop tools for teacher support and encouragement in their future teaching practice. 
An analysis of the papers about experimental work revealed various focuses of the research in this field. The first group of papers dealt with the development of new experimental procedures and special equipment for the school chemistry laboratory. The paper by Zupančič-Brouwer, Glažar and Vrtačnik (200o) described the development of a new experimental method that could be used in teaching and learning acid-base concepts. In the described method, a soft medium based on flour was used as a reaction medium to carry out chemical reactions that can normally run in water solution. Gros and Vrtačnik (2005) proposed the design and application of a small-scale portable gas chromatograph for hands-on learning of the basic concepts of chromatography. The operation of the instrument was optimised so that it offers a low-cost solution for presenting chromatography that does not require the use of a computer for recording data.

In a follow-up paper, researchers (Vrtačnik \& Gros, 2013) evaluated the effect of introducing visible spectrometry concepts through hands-on laboratory work within four vocational programmes. The results showed no correlation between students' motivational components (intrinsic, regulated and controlled), their chemistry self-concept and their achievement in an experiential knowledge test, on the one hand, and knowledge gained from the hands-on approach, on the other. All of the students, regardless of their study programme, gave a positive evaluation of the relaxed atmosphere that contributed to their self-confidence in completing their laboratory activities. With regard to the described hands-on approach to visible spectrometry, the researchers (Juriševič, Vrtačnik, Kwiatkowski, \& Gros, 2012) also aimed to determine the relationship between students' motivational orientations and their chemistry achievements, based on a sample of students from Polish and Slovenian vocational and technical high schools. The results indicated that hands-on laboratory work with autonomy-supportive teachers could create a motivating learning environment for students to learn with understanding and to cooperate with each other in academic tasks at a higher level of cognitive complexity.

The main focus of further articles in this field was the evaluation of students' cognitive achievements gained through hands-on experimental work related to selected content. Pavlin, Vaupotič, Glažar, Čepič and Devetak (2011) evaluated students' general conceptions related to liquid crystals and their properties, as well as to the state of matter in general. The students' achievements depended on their gender, their self-assessed knowledge of liquid crystals, and their field of study. Based on the results of the study, learning units were developed to stimulate students' knowledge development about liquid crystals. The researchers (Urbančič \& Glažar, 2012) also studied the impact of experimental 
work on the understanding of scientific concepts. The results show that one third of the pupils in the experimental group were unable to write down even one experiment they remembered from science classes; of the remaining two thirds of the pupils who wrote down at least one experiment, none of them managed to describe it correctly. Although they were unable to describe the experiments, the students' achievements in the experimental group were significantly higher than those in the control group. The results also show that pupils believe experiments to be the most popular part of science classes. The research by Herga, Glažar and Dinevski (2015) examined the classroom application of a virtual laboratory in integrating the triple levels of chemistry. The results revealed that, in terms of knowledge acquisition, the use of a virtual laboratory improved pupil performance relative to pupils who did not use elements of dynamic visualisation in the classroom, and that the virtual laboratory positively influenced pupils' understanding of selected chemical concepts.

Researchers (Logar \& Ferk Savec, 2011) also focused on an evaluation of the effectiveness of different forms of experimental work. The results indicated that student content knowledge gained through a teacher's demonstration of an experiment was better, and with better knowledge retention, than student knowledge gained through students' hands-on experimental work. However, most of the interviewed students stated that they preferred conducting experiments themselves rather than observing a teacher's demonstration. A followup study (Logar, Peklaj, \& Ferk Savec, 2017) aimed to provide further details related to the effectiveness of student learning based on experimental work in primary schools. The results identified eight factors that seem to be the most important for effective student learning, of which four factors are part of the teacher's preparation for experimental work, and the other four are related to the thoughtful implementation of experimental work in the classroom.

\section{Conceptions of Basic Chemical Concepts}

Another influential area of research is Conceptions of Basic Chemical Concepts. Eight papers were published in this area. The number of citations achieved by some of the papers is shown in Table 5 . 
Table 5

Characteristics of the analysed papers that met the inclusion criteria in the research field Conceptions of Basic Chemical Concepts (listed according to publication year)

\begin{tabular}{|c|c|c|}
\hline Authors & Title & Characteristics* \\
\hline $\begin{array}{l}\text { Krnel, D., Watson, R., } \\
\text { Glažar, S. A. }\end{array}$ & $\begin{array}{l}\text { Survey of research related to the } \\
\text { development of the concept of } \\
\text { "matter" }\end{array}$ & $\begin{array}{l}\text { J: International Journal of Science } \\
\text { Education } \\
\text { ISSN: } 0950-069 ; \text { PY: 1998; PP: 32; } \\
\text { NoR: } 101 \\
\text { NoCit: Wos } 51 \quad \text { Scopus } 76\end{array}$ \\
\hline $\begin{array}{l}\text { Vrtačnik, M., Ferk } \\
\text { Savec, V., Dolničar, } \\
\text { D., Zupančič- } \\
\text { Brouwer, N., } \\
\text { Sajovec, M. }\end{array}$ & $\begin{array}{l}\text { The impact of visualisation on the } \\
\text { quality of chemistry knowledge }\end{array}$ & $\begin{array}{l}\text { J: Informatica: An International Jour- } \\
\text { nal of Computing and Informatics } \\
\text { ISSN: 0350-5596; PY: 2000; PP: 6; } \\
\text { NoR: } 19 \\
\begin{array}{l}\text { NoCit: } \quad \text { Scopus } 1\end{array}\end{array}$ \\
\hline $\begin{array}{l}\text { Vrtačnik, M., Sajovec, } \\
\text { M., Dolničar, D., } \\
\text { Razdevšek-Pučko, } \\
\text { C., Glažar, S. A., } \\
\text { Zupančič-Brouwer, } \\
\text { N. }\end{array}$ & $\begin{array}{l}\text { An interactive multimedia tutorial } \\
\text { teaching unit and its effects on } \\
\text { student perception and under- } \\
\text { standing of chemical concepts }\end{array}$ & $\begin{array}{l}\text { J: Westminster Studies in Education } \\
\text { ISSN: 0140-6728; PY: 2000; PP: 14; } \\
\text { NoR: } 14\end{array}$ \\
\hline $\begin{array}{l}\text { Krnel, D., Glažar, S. } \\
\text { A., Watson, R. }\end{array}$ & $\begin{array}{l}\text { The development of the concept } \\
\text { of "matter": a cross-age study of } \\
\text { how children classify materials }\end{array}$ & $\begin{array}{l}\text { J: Science Education } \\
\text { ISSN: 0036-8326; PY: 2003; PP: 18; } \\
\text { NoR: } 42 \\
\text { NoCit: Wos } 23 \quad \text { Scopus } 35\end{array}$ \\
\hline $\begin{array}{l}\text { Krnel, D., Watson, R., } \\
\text { Glažar, S. A. }\end{array}$ & $\begin{array}{l}\text { The development of the concept } \\
\text { of "mater": a cross-age study of } \\
\text { how children describe materials }\end{array}$ & $\begin{array}{l}\text { J: International Journal of Science } \\
\text { Education } \\
\text { ISSN: 0950-0693; PY: 2005; PP: 16; } \\
\text { NoR: } 51 \\
\text { NoCit: Wos } 10 \quad \text { Scopus } 18\end{array}$ \\
\hline $\begin{array}{l}\text { Devetak, I., Drofenik } \\
\text { Lorber, E., Juriševič, } \\
\text { M., Glažar, S. A. }\end{array}$ & $\begin{array}{l}\text { Comparing Slovenian year } 8 \text { and } \\
\text { year } 9 \text { elementary school pupils' } \\
\text { knowledge of electrolyte chemis- } \\
\text { try and their intrinsic motivation }\end{array}$ & $\begin{array}{l}\text { J: Chemistry Education Research and } \\
\text { Practice } \\
\text { ISSN: 1109-4028; PY: 2009; PP: 9; } \\
\text { NoR: } 43 \\
\text { NoCit: Wos } 9 \quad \text { Scopus } 12\end{array}$ \\
\hline $\begin{array}{l}\text { Slapničar, M., } \\
\text { Devetak, I., Glažar, S. } \\
\text { A., Pavlin, J. }\end{array}$ & $\begin{array}{l}\text { Identification of the understanding } \\
\text { of the states of matter of water } \\
\text { and air among Slovenian students } \\
\text { aged } 12,14 \text { and } 16 \text { years through } \\
\text { solving authentic tasks }\end{array}$ & $\begin{array}{l}\text { J: Journal of Baltic Science Education } \\
\text { ISSN: 1648-3898; PY: 2017; PP: 15; } \\
\text { NoR: } 48 \\
\text { NoCit: Wos } 2 \quad \text { Scopus } 2\end{array}$ \\
\hline $\begin{array}{l}\text { Slapničar, M., Tompa, } \\
\text { V., Glažar, S. A., } \\
\text { Devetak, I. }\end{array}$ & $\begin{array}{l}\text { Fourteen-year-old students' } \\
\text { misconceptions regarding the } \\
\text { sub-micro and symbolic levels of } \\
\text { specific chemical concepts }\end{array}$ & $\begin{array}{l}\text { J: Journal of Baltic Science Education } \\
\text { ISSN: 1648-3898; PY: 2018; PP: 12; } \\
\text { NoR: } 35 \\
\text { NoCit: Wos } 0 \quad \text { Scopus } 0\end{array}$ \\
\hline
\end{tabular}

Note. $\mathrm{J}=$ Journal; $\mathrm{PY}=$ Publication Year; $\mathrm{PP}=$ No. of pages; $\mathrm{R}=$ No. of references; NoCit $=$ Number of citations in Web of Science (WoS) and Scopus (citations until 16.08.19).

In this period, three papers by three authors in the area of early science education chemistry concept development were published. All three papers presented specific parts of the same study, in which the development of the 
concept of matter was explored by interviewing 84 students aged 3-13 in Slovenia. The children were asked to describe objects and substances. The patterns of the responses indicate that children first develop prototypes for substances by acting on objects and substances. This is followed by increasing the use of properties to describe objects and substances, leading to a growing awareness of the distinction between the intensive properties of matter and the extensive properties of objects. Through their actions, children gradually develop a more elaborated schema that enables them to distinguish between extensive and intensive properties, and hence between object and matter (Krnel, Glažar, \& Watson, 2003; Krnel, Watson, \& Glažar, 1998, 2005).

Lower and secondary school education chemistry concept development was discussed in three papers. Slapničar, Tompa, Glažar and Devetak (2018) aimed to identify potential misconceptions of chemical concepts: the states of matter, a pure substance, a mixture, an element, a compound, a physical change, and a chemical reaction at the submicro level when solving problems incorporating submicrorepresentations. The results showed that the majority of students had formed inadequate mental models (misconceptions) for the chemical concept of the liquid state of water (66.5\%). The lowest level of misconceptions is related to the gaseous state of matter, with almost all of the students $(98.5 \%)$ solving the problem correctly. The aim of the research presented in the next paper by Slapničar, Devetak, Glažar and Pavlin (2017) was to identify how Slovenian primary and secondary school students of various age groups (12, 14 and 16 yearolds) explain the particulate nature of the states of matter of water and air. The results show that all of the students correctly identified the states of matter of water at the particulate level, but not of air. The study confirmed the existence of (a) misconceptions regarding the interpretation of the particulate nature of matter, (b) a failure to distinguish between particle and matter, and (c) the inadequate description of the submicroscopic level of matter with a macroscopic level concept. The last study presented in this context, by Devetak, Drofenik Lorber, Juriševič and Glažar (2009), was undertaken to illustrate the most drastic general curriculum change in the Slovenian school system. It explored the differences between eight-year primary school pupils (before the curriculum reform) and nine-year primary school pupils (soon after the curriculum reform) with regard to specific chemistry knowledge and motivation to learn chemistry. The results show that pupils of nine-year primary school do not achieve significantly better chemistry knowledge test scores than eight-year elementary school pupils. Similar results were obtained when comparing intrinsic motivation. It can be concluded that students develop different misconceptions of selected chemical concepts no matter what type of school they attend. 
The last two papers discussed the impact of visualisations on chemistry concept understanding. The first study, by Vrtačnik, Ferk Savec, Dolničar, Zupančič-Brouwer and Sajovec (2000), examined the impact of a long-term project entitled Computer Literacy, which equipped the majority of Slovenian primary and secondary schools with multimedia computers and LCD projectors. The authors discussed how chemistry teachers can use specialised Internet websites for visualising chemical structures and processes on the macroscopic and microscopic level and correlate properties of molecules with their structure. The presented results demonstrate the effects of different visualisation elements on the quality of chemical knowledge.

In their study, Vrtačnik, Sajovec, Dolničar, Razdevšek-Pučko, Glažar and Zupančič-Brouwer (2000) researched the effects of an interactive multimedia tutorial unit on students' perception of the new learning environment and their understanding of chemical concepts. Based on the findings, it is possible to conclude that chemistry can be considered a difficult and rather unpopular school subject. No significant differences in these perceptions can be found regarding the students' chemistry grade or their average study grade. Multimedia should therefore be used in teaching with a certain degree of caution, and only after a short introduction to the concepts presented in the unit has been given. Nevertheless, regardless of the mixed feelings about the new learning environment, the multimedia teaching unit has promising effects on students' acquisition of knowledge.

\section{Conclusions}

The main focus of this paper was to review the characteristics of Slovenian papers published between 1991 and 2019 and identify the main findings that could help to determine which aspects teachers should consider when teaching abstract chemical concepts at all levels of chemistry education. Four major fields of chemical education research emerged from the analysis: (1) Submicro Representations, Models and Animations, (2) Chemistry Teacher Education, (3) Experimental Work, and (4) Conceptions of Basic Chemical Concepts.

Papers published in the first field have had the greatest impact on the international research community. It is important to emphasise, as Juriševič et al. (2012) conclude, that the main implication for teachers in chemistry classes is to plan their teaching more systematically and creatively in order to provide students with individualised, cognitively and motivationally challenging learning situations, and to foster learning with understanding even within very abstract and cognitively complex learning activities. Such activities can contribute 
to diminishing existing misconceptions and preventing the formation of new ones.

Another aspect of bridging the rifts between chemical education research and classroom practice could be addressed by forming a journal (indexed in international databases) dedicated to in-service chemistry teachers. This would also provide an opportunity for researchers to publish their manuscripts. However, in-service chemistry teachers should be part of innovative teaching and learning approaches, such as participatory action research that combines theoretical knowledge and practical experience in mixed teams of university personnel, in-service and preservice teachers (Tolsdorf \& Markić, 2018). A major part of these activities should comprise reading research papers, whereby students would learn how to use such materials to their advantage in planning effective teaching.

\section{Acknowledgment}

The authors wish to thank Andreja Grčar, Nina Zupanc, Luka Vinko and Aljaž Debelak for conducting the initial research for the purpose of this paper in specific databases and for gathering the references used in the papers analysed.

\section{References}

Devetak, I., \& Ferk Savec, V. (2018). Chemical education in Slovenia: Past experiences and future challenges. In C. T. Cox \& W. E. Schatzberg, (Eds.), International perspectives on chemistry education, research, and practice (pp. 205-219). Washington, D.C.: American Chemical Society.

Devetak, I., \& Glažar, S. A. (2010). The influence of 16-year-old students' gender, mental abilities, and motivation on their reading and drawing submicrorepresentations achievements. International Journal of Science Education, 32(12), 1561-1593.

Devetak, I. (Ed.). (2007). Elementi vizualizacije pri pouku naravoslovja [Elements of visualisation in science teaching]. Ljubljana: University of Ljubljana, Faculty of Education.

Devetak, I., \& Metljak, M. (Eds.). (2014). PROFILES: Inovativno poučevanje naravoslovja in spodbujanje naravoslovne pismenosti v osnovni in srednji šoli [PROFILES: Innovative science teaching and promoting science literacy in primary school and high school]. Ljubljana: University of Ljubljana, Faculty of Education.

Devetak, I., Drofenik Lorber, E., Juriševič, M., \& Glažar, S. A. (2009). Comparing Slovenian year 8 and year 9 elementary school pupils' knowledge of electrolyte chemistry and their intrinsic motivation. Chemistry Education Research and Practice, 10(4), 281-290.

Devetak, I., Hajzeri, M., Glažar, S. A., \& Vogrinc, J. (2010). The influence of different models on 
15-years-old students' understanding of the solid state of matter. Acta Chimica Slovenica, 57(4), 904-911.

Devetak, I., Urbančič, M., Wissiak Grm, K. S., Krnel, D., \& Glažar, S. A. (2004). Submicroscopic representations as a tool for evaluating students' chemical conceptions. Acta Chimica Slovenica, 51(4), 799-814.

Devetak, I., Vogrinc, J., \& Glažar, S. A. (2009). Assessing 16-year-old students' understanding of aqueous solution at submicroscopic level. Research in Science Education, 39(2), 157-179.

Devetak, I., Vogrinc, J., \& Glažar, S. A. (2010). States of matter explanations in Slovenian textbooks for students aged 6 to 14. International Journal of Environmental and Science Education, 5(2), 217-235. Ferk Savec, V., \& Devetak, I. (2013). Evaluating the effectiveness of students' active learning in chemistry. Procedia - Social and Behavioral Sciences, 106, 1113-1121.

Ferk Savec, V., \& Devetak, I. (Eds.). (2017). Učitelj raziskovalec na področju poučevanja kemijskih vsebin [The teacher as a researcher in the teaching of chemical content]. Ljubljana: University of Ljubljana, Faculty of Education.

Ferk Savec, V., \& Wissiak Grm, K. S. (2017). Development of chemistry pre-service teachers during practical pedagogical training: Self-evaluation vs. evaluation by school mentors. Acta Chimica Slovenica, 64(1), 63-72.

Ferk Savec, V., Hrast, Š., Devetak, I., \& Torkar, G. (2016). Beyond the use of an explanatory key accompanying submicroscopic representations. Acta Chimica Slovenica, 63(4), 864-873.

Ferk Savec, V., Hrast, Š., Šuligoj, V., \& Avsec, S. (2018). The innovative use of ICT in STEM teacher training programmes at the University of Ljubljana. World Transactions on Engineering and Technology Education, 16(4), 421-427.

Ferk Savec, V., Urankar, B., Aksela, M., \& Devetak, I. (2017). Prospective chemistry teachers' perceptions of their profession: The state of the art in Slovenia and Finland. Journal of the Serbian Chemical Society, 82(10), 1193-1210.

Ferk Savec, V., Vrtačnik, M., Blejec, A., \& Gril, A. (2003) Students' understanding of molecular structure representations. International Journal of Science Education, 25(10), 1227-1245.

Ferk Savec, V., Vrtačnik, M., Gilbert, J. K., \& Peklaj, C. (2006). In-service and pre-service teachers' opinion on the use of models in teaching chemistry. Acta Chimica Slovenica, 53(3), 381-390.

Glažar, S. A., Wissiak Grm, K. S., \& Devetak, I. (Eds). (2019). Učitelj raziskovalec za prenos raziskovalnih spoznanj v pouk kemije [The teacher as a researcher for transferring research to chemistry lessons]. Ljubljana: University of Ljubljana, Faculty of Education.

Gros, N., \& Vrtačnik, M. (2005). Cost-effective teacher a small-scale low-cost gas chromatograph. Journal of Chemical Education, 82(2), 291-293.

Grubelnik, V. (Ed.). (2010). Opredelitev naravoslovnih kompetenc [Defining science competences].

Maribor: University of Maribor, Faculty of Natural Sciences and Mathematics.

Herga, N. A. R., GlaŽar, S. A., \& Dinevski, D. (2015). Dynamic visualization in the virtual laboratory enhances the fundamental understanding of chemical concepts. Journal of Baltic Science Education, $14(3), 351-365$. 
Hrast, Š., \& Ferk Savec, V. (2017a). Informational value of submicroscopic representations in Slovenian chemistry textbook sets. Journal of Baltic Science Education, 16(5), 694-705.

Hrast, Š., \& Ferk Savec, V. (2017b). The integration of submicroscopic representations used in chemistry textbook sets into curriculum topics. Acta Chimica Slovenica, 64(4), 959-967. Juriševič, M., Vrtačnik, M., Kwiatkowski, M., \& Gros, N. (2012). The interplay of students' motivational orientations, their chemistry achievements and their perception of learning within the hands-on approach to visible spectrometry. Chemistry Education Research and Practice, 13(3), $237-247$.

Kornhauser A. (1979). Trends in research in chemical education. European Journal of Science Education, 1(1), 21-50.

Kousa, P., Aksela, M., \& Ferk Savec, V. (2018). Pre-service teachers' beliefs about the benefits and challenges of STSE based school-industry collaboration and practices in science education. Journal of Baltic Science Education, 17(6), 1034-1045.

Krnel, D., Glažar, S. A. \& Watson, R. (2003). The development of the concept of “matter": A cross-age study of how children classify materials. Science Education, 87(5), 621-639.

Krnel, D., Watson, R., \& Glažar, S. A. (1998). Survey of research related to the development of the concept of "matter". International Journal of Science Education, 20(3), 257-289.

Krnel, D., Watson, R., \& Glažar, S. A. (2005). The development of the concept of “matter": A crossage study of how children describe materials. International Journal of Science Education, 27(3), $367-383$.

Logar, A., \& Ferk Savec, V. (2011). Students' hands-on experimental work school chemistry. Acta Chimica Slovenica, 58(4), 866-875.

Logar, A., Peklaj, C., \& Ferk Savec, V. (2017). Effectiveness of student learning during experimental work in primary school. Acta Chimica Slovenica, 64(3), 661-671.

Moher D., Liberati A., Tetzlaff J., Altman D. G., \& The PRISMA Group (2009). Preferred reporting items for systematic reviews and meta-analyses: The PRISMA statement. PLOS Medicine, 6(7), e1000097.

Nuić, I., \& Glažar, S. A. (2015). Application of web-based learning material for teaching states of matter in 8th grade primary school chemistry - a pilot study results. Glasnik hemičara i tehnologa Bosne i Hercegovine, 45, 43-50.

Pavlin, J., Glažar, S. A., Slapničar, M., \& Devetak, I. (2019). The impact of students' educational background, interest in learning, formal reasoning and visualisation abilities on gas context-based exercises achievements with submicro-animations. Chemistry Education Research and Practice, 2o(3), $633-649$.

Pavlin, J., Vaupotič, N., Glažar, S. A., Čepič, M., \& Devetak, I. (2011). Slovenian pre-service teachers' conceptions about liquid crystals. Eurasia Journal of Mathematics, Science and Technology Education, $7(3), 173-180$.

Sikošek, D. (2009a). Student self-evaluation of co-lecture activities. Problems of Education in the 21st Century, 14, 116-122. 
Sikošek, D. (2009b). Student self-evaluation of seminar activities. Problems of Education in the 21st Century, 14, 109-115.

Sikošek, D., \& Žarić, K. (2013). Implementation of process-targeted activities of prospective chemistry teachers during continuous teaching practice: A rational comparative analysis of teaching methods according to the expressed competencies. Problems of Education in the 21st Century, 53, $74-88$.

Sikošek, D., \& Žuželj, M. (2013). Using chemical models for developing natural science competences in teaching chemistry: From pupils as model assemblers to pupils as creators of self-made models. Problems of Education in the 21st Century, 53, 89-98.

Slapničar, M., Devetak, I., Glažar, S. A., \& Pavlin, J. (2017). Identification of the understanding of the states of matter of water and air among Slovenian students aged 12, 14 and 16 years through solving authentic tasks. Journal of Baltic Science Education, 16(3), 308-323.

Slapničar, M., Tompa, V., Glažar, S. A., \& Devetak, I. (2018). Fourteen-year-old students' misconceptions regarding the sub-micro and symbolic levels of specific chemical concepts. Journal of Baltic Science Education, 17(4), 620-632.

Smith, V., Devane, D., Begley, C. M., \& Clarke, M. (2011). Methodology in conducting a systematic review of systematic reviews of healthcare interventions. BMC Medical Research Methodology, 11(1), $15-16$.

Tolsdorf, Y., \& Markić, S. (2018). Participatory action research in university chemistry teacher training. Center for Educational Policy Studies Journal, 8(4), 89-108.

Torkar, G., \& Devetak, I. (2017). Pre-service preschool and primary school teachers' science education. In B. Saqipi \& J. Vogrinc (Eds.). The Prospects of Reforming Teacher Education, (pp. 111-136). Prishtinë: Shtëpia Botuese Libri Shkollor.

Torkar, G., Veldin, M., Glažar, S. A., \& Podlesek, A. (2018). Why do plants wilt? Investigating students' understanding of water balance in plants with external representations at the macroscopic and submicroscopic levels. Eurasia Journal of Mathematics, Science and Technology Education, 14(6), 2265-2276.

Urbančič, M., \& Glažar, S. A. (2012). Impact of experiments on 13-year-old pupils' understanding of selected science concepts. Eurasia Journal of Mathematics, Science and Technology Education, 8(3), 207-218.

Vrtačnik, M., \& Gros, N. (2013). The Impact of a hands-on approach to learning visible spectrometry upon students' performance, motivation, and attitudes. Acta Chimica Slovenica, 6o(1), 209-220. Vrtačnik, M., Ferk Savec, V., Dolničar, D., Zupančič-Brouwer, N., \& Sajovec, M. (200o). The impact of visualisation on the quality of chemistry knowledge. Informatica: An International Journal of Computing and Informatics, 24(4), 497-503.

Vrtačnik, M., Sajovec, M., Dolničar, D., Razdevšek-Pučko, C., Glažar, S. A., \& Zupančič-Brouwer, N. (2000). An interactive multimedia tutorial teaching unit and its effects on student perception and understanding of chemical concepts. Westminster Studies in Education, 23(1), 91-105.

Wissiak Grm, K. S., \& Ferk Savec, V. (2013). Bridging the gap between educational research and 
school practice through cooperation of university and primary school teachers. Procedia - Social and Behavioral Sciences, 106, 576-584.

Wissiak Grm, K. S., \& Ferk Savec, V. (2014). The self-evaluation of Slovenian prospective chemistry teachers' progress during their practical pedagogical training in primary schools. Acta Chimica Slovenica, 61(4), 729-739.

Zupančič-Brouwer, N., Glažar, S. A., \& Vrtačnik, M. (2000). Using starch to dispense indicators and reagents. Acta Chimica Slovenica, 1(47), 81-88.

\section{Biographical note}

Iztok Devetak, PhD, is Full Professor of chemical education at University of Ljubljana, Faculty of Education, Slovenia. His research focuses on students' chemistry learning and their motivation, how chemistry in context stimulates learning using eye-tracking technology in explaining science learning, aspects of environmental education, and the development of teachers' health-managing competences.

Vesna Ferk Savec, PhD, is a full professor in chemical education at the Faculty of Education, University of Ljubljana, Slovenia. Her current research interests are focused primarily on visualization of the triple nature of chemical concepts and processes, the integration of ICT in teaching and learning, the implementation of green chemistry in school practice and society, creativity and the relevancy of schools-university-industry collaboration in STEM area. 